\title{
Seismic crustal structure in the southwest of the Iberian Peninsula and the Gulf of Cadiz
}

\author{
Antonio González ${ }^{\mathrm{a}, *}$, Diego Córdoba ${ }^{\mathrm{a}}$, Ramón Vegas ${ }^{\mathrm{b}}$, Luis M. Matias $^{\mathrm{c}}$ \\ - Departamento de Geofisica, Facultad de Ciencias Físicas, Universidad Complutense, 28040 Madrid, Spain \\ ${ }^{b}$ Departamento de Geodinámica, Facultad de Ciencias Geológicas, Universidad Complutense, 28040 Madrid, Spain \\ ${ }^{c}$ Centro de Geofisica da Universidade de Lisboa, Rua da Escola Politécnica 58, 1200 Lisbon, Portugal
}

\begin{abstract}
The crust under the southwestern Iberian Peninsula and the Gulf of Cadiz has been sampled by $1200 \mathrm{~km}$ of deep seismic refraction/wide-angle reflection profiles, together with many seismic reflection lines and bore-holes. Wide-angle seismic data were collected during the last three decades. Commercial multichannel data provide a detailed image of the uppermost crust, improving the confidence about the models of the deeper structures. P-wave velocities within the thick column of sediments in the Gulf of Cadiz range from 2.0 to $3.8 \mathrm{~km} / \mathrm{s}$, while the Algarve and the Sines areas have higher velocities of 4.3 to $4.8 \mathrm{~km} / \mathrm{s}$. The top of the Palaeozoic basement rises to the northwest, outcropping in the South Portuguese zone of the Iberian Massif, and is characterized by P-wave velocities of $5.7-5.9 \mathrm{~km} / \mathrm{s}$. High velocities of $6.4 \mathrm{~km} / \mathrm{s}$ have been found at shallow depths of 7 to $10 \mathrm{~km}$ in the South Portuguese zone, that could be related to the mafic and ultramafic rocks in the Beja-Acebuches zone. Lower crustal velocities are in the range of $6.7-6.9 \mathrm{~km} / \mathrm{s}$. The crustal thickness shows important lateral changes from $29 \mathrm{~km}$ beneath the Guadalquivir Basin/Iberian Massif contact to $35 \mathrm{~km}$ in the southeastern part of the South Portuguese zone. From the interpretation of these seismic data, a geodynamic model of the evolution of the crust in Southwestern Iberia and the Gulf of Cadiz is proposed. The Guadalquivir Basin, and its continuation at sea, the Gulf of Cadiz, is a flexure area of the crust that could be related to the overloading due to the overthrusting of the Alboran Domain over the Iberian plate.
\end{abstract}

Keywords: crustal structure; seismic profiles; Iberian Peninsula; Gulf of Cadiz; tectonics

\section{Introduction}

A number of deep seismic refraction/wide-angle reflection profiles were carried out in the southwest of the Iberian Peninsula and the Gulf of Cadiz, during the last three decades. Part of these data were recorded in the seventies in southern Portugal, using portable seismic stations with analog recording in modulated frequency. Results from these first experiments in the Iberian crust, obtained from analog data processing and plotting of record-sections, were published by Mueller et al. (1973), Prodehl et al. (1974) and Sousa Moreira et al. (1977). In the eighties, additional experiments were performed in the southwest of Spain, using the same techniques as used in the Portuguese profiles, using sea shots as energy source and recording seismic signals in portable ana- 
log recording equipment. These data were digitized and its interpretation, based on P-wave travel-time analysis, allowed to obtain a model for the distribution of P-wave velocities in the western end of the Betic Cordillera and the southwest of the Iberian Peninsula. Grupo de Trabajo de perfiles sísmicos profundos (1983) presented part of the data used in the present paper and a preliminary crustal model interpretation. However, in the present paper we propose a new phase correlation, obtaining a new model in the eastern Gulf of Cadiz. Medialdea (1983) and Medialdea et al. (1986) studied an area more to the east. In the present paper one of the profiles of Medialdea (1983) and Medialdea et al. (1986) is reinterpreted. In 1989, the ILIHA project (ILIHA DSS Group, 1993) provided a new data set across the southwest of the Iberian Peninsula, covering two new lines along different azimuths. There is a previous interpretation of these data (González et al., 1994) based on the travel-time of P-wave arrivals observed on seismograms. Commercial seismic reflection information (Repsol Company, unpublished) acquired over a wide area of the Gulf of Cadiz has revealed a wealth of structural details in the shallow crust. These seismic reflection studies (seismic reflection transects, isopach maps) are complemented by bore-holes (Repsol Company, unpublished data, and Instituto Geológico y Minero de España, 1987). This new data set allows a joint interpretation of all the deep seismic sounding and seismic reflection data, together with structural information of the upper crust. Thus, geological constraints were incorporated into the modelling, resulting in a better picture of the upper crustal structure and more confidence for interpreting the deeper structures.

\section{Geological setting}

The studied area corresponds to the southwestern corner of the Iberian Peninsula, where the Iberian Massif and the western end of the Betic Cordillera are connected through the Guadalquivir Basin. The Gulf of Cadiz represents the continuation of this basin in the continental margin and the Algarve margin the Mesozoic border of the Iberian Massif (Fig. 1).

The Iberian Massif forms part of the Variscan Belt of central Europe that resulted from the late Palaeo- zoic suture of Gondwana and Laurasia. Within this plate context, the Iberian Massif is a consequence of a complex assembly of several terranes forming the Upper Proterozoic-lower Palaeozoic passive margin of Gondwana as well as other back-arcderived domains coming from the upper Palaeozoic plate convergence. Among these terranes, the OssaMorena and South Portuguese zones can be considered (Dallmayer and Martínez García, 1992 and references therein).

The South Portuguese zone is characterized by the exclusive occurrence of upper Palaeozoic formations affected by low-grade metamorphism and disposed, in a broad sense, as a foreland, SW-vergent, fold and thrust belt. It is worth to mention in this zone the existence of an ophiolite band related to rocks presumably deposited upon an oceanic-like crust, the Pulo do Lobo Antiform. These formations have been ascribed to a small oceanic area situated between the Ossa-Morena and South Portuguese zones during the middle Palaeozoic. The obliteration of this oceanic realm gave rise to the emplacement of the Beja-Acebuches ophiolite and the overthrusting of the Ossa-Morena zone onto the northern border of the South Portuguese zone (Fig. 1).

The other main crustal domain of the study area corresponds to the westernmost end of the Betic Cordillera, the northern half of the Gibraltar arc (Fig. 1), where three different tectonic units concur: the Subbetics, the deformed Mesozoic margin of the Iberian Massif; the Flysch Trough units corresponding to a basin situated off the Mesozoic margin; and the Alboran Domain, an extra-Iberian crustal unit that was situated eastward of its present location. The relative positions of these tectonic units are the result of the Upper Cretaceous up to Present convergence of Africa and Europe. This convergence caused the westward displacement of the Alboran Domain (through a sort of crustal extrusion), the obliteration of the Flysch Through Basin and the subsequent overthrusting of the Alboran Basin onto both the African and Iberian Mesozoic margins, forming the Gibraltar Arc. As a consequence, during the Miocene, the crust was thickened around the Gibraltar Arc by means of a major crustal thrust (Balanyá and García-Dueñas, 1988). Nevertheless, this region was almost simultaneously affected by a generalized crustal stretching with the negative in- 


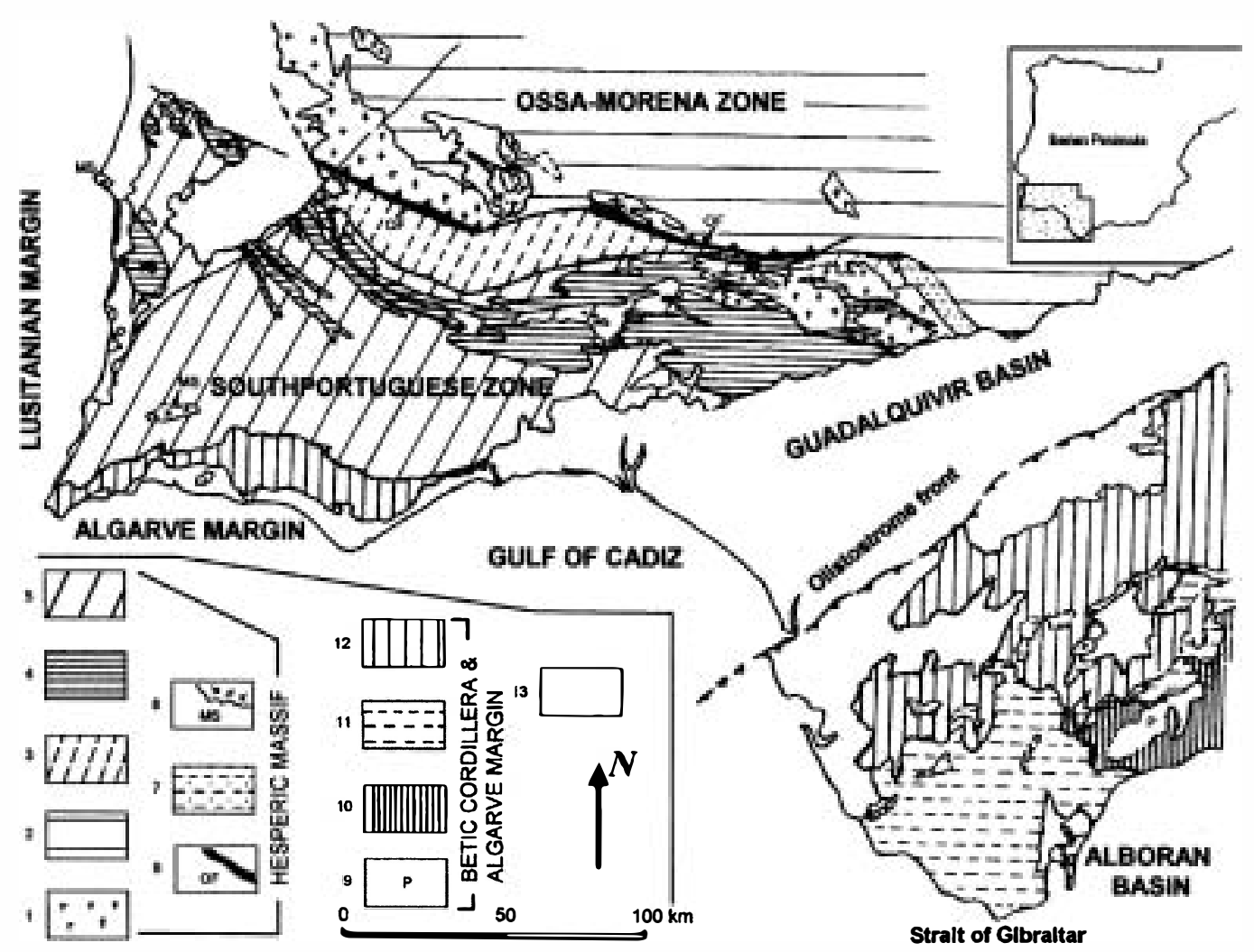

Fig. 1. Simplified geological map of the studied area: $1=$ late Hercynian granitoids; $2=$ Upper Proterozoic-lower Palaeozoic metasediments of the Ossa-Morena zone; 3 = Pulo do Lobo Antiform formations; 4 = Pyrite Belt; $5=$ Carboniferous Flysch of Southern Portugal; $6=$ Beja-Acebuches ophiolite; $7=$ Upper Carboniferous-Lower Permian Molasse; $8=$ Mesozoic intrusives of Sines and Monchique; $9=$ peridotites of Ronda, included in the Alboran Domain; $10=$ Alboran Domain; $11=$ Flysch Trough units (Upper Cretaceous-Neogene); 12 = Subbetics; $13=$ Neogene and Quaternary basins.

version of the thrusts causing the formation of the Alboran Basin (García-Dueñas and Balanyá, 1991).

The Guadalquivir Basin, and its extension to the Gulf of Cadiz continental margin, can be considered as the foreland basin of the western Betic Cordillera, while the Algarve margin can be regarded as equivalent of the Subbetics in an area that escaped from the Betic deformation, i.e., crustal thickening and thinning in the frame of the westward displacement of the Alboran Domain.

\section{Data description}

The map shown in Fig. 2 displays the deep seismic soundings discussed in this paper and the locations of the sea shots.
Ayamonte-Trafalgar (see line 1 in Fig. 2) is a marine seismic refraction/wide-angle reflection profile crossing the Gulf of Cadiz in a NW-SE direction. This profile was carried out in 1981 and has yielded information on the offshore velocity structure of the crust in this area. The profile length is $169 \mathrm{~km}$, with $13 \mathrm{~km}$ of sea shot spacing. Two portable seismic stations were located at both ends of the line to record the thirteen shots detonated along the profile. The Trafalgar records are noisy and useless, due to local bad weather conditions. Taking advantage of the shots of the Ayamonte-Trafalgar line, additional land stations were deployed along the Chipiona-Arcos de la Frontera and Trigueros-Santa Olalla lines (lines 2 and 3 in Fig. 2), to sample the Subbetics and the Iberian Massif, respectively.

The Chipiona-Arcos de la Frontera profile (line 2 


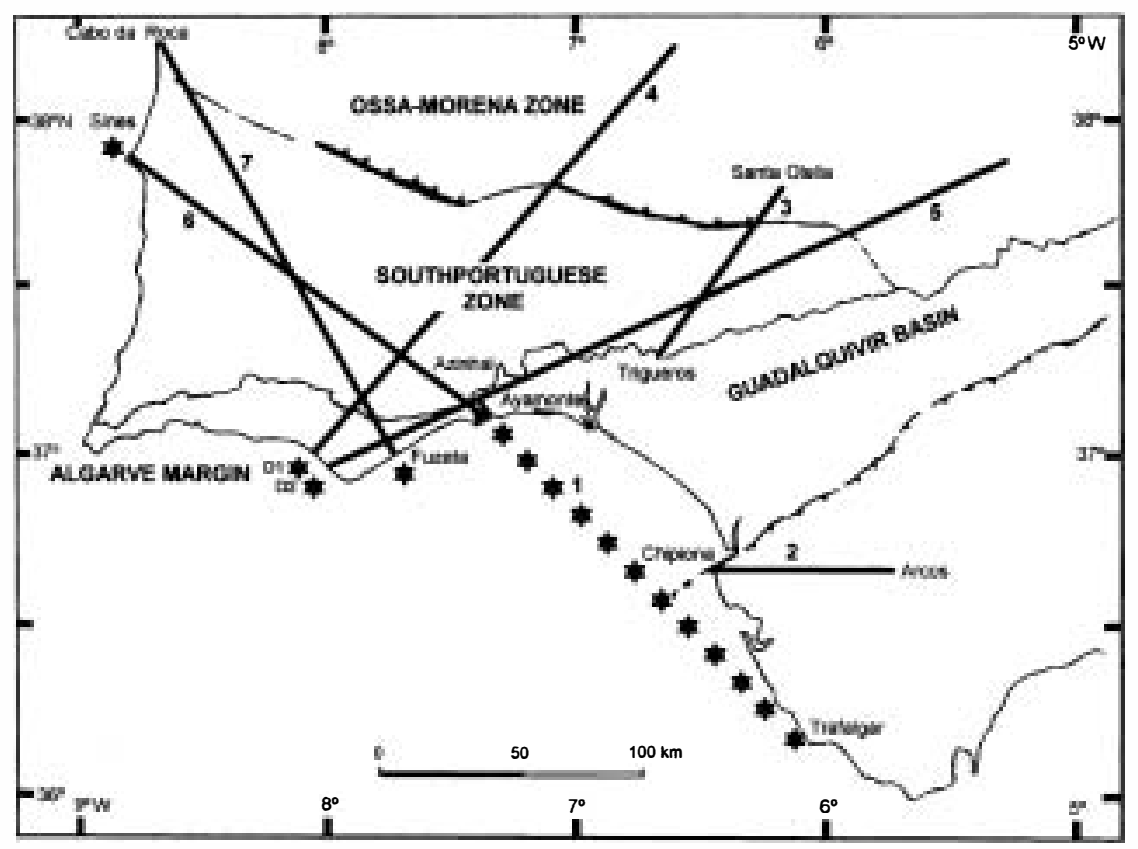

Fig. 2. Heavy lines, seismic refraction/wide-angle profiles: $1=$ Ayamonte-Trafalgar; $2=$ Chipiona-Arcos de la Frontera; $3=$ Trigueros-Santa Olalla; $4=$ ILIHA D1; $5=$ ILIHA D2; $6=$ Sines-Azinhal; $7=$ Fuzeta-Cabo da Roca. Stars show shotpoints used to obtain wide-angle seismic reflection/refraction profiles discussed in text.

in Fig. 2) runs along a line of $63 \mathrm{~km}$ length, with an average station spacing of $3 \mathrm{~km}$. The primary aim of this profile was to probe the deformation front of the Betic orogen. The shotpoint, which is similar to one of the shots fired for the Ayamonte-Trafalgar profile, is located $30 \mathrm{~km}$ offshore. Therefore, recording stations were situated at offsets exceeding this distance. Deep exploration bore-holes and marine reflection seismic lines (Instituto Geológico y Minero de España, 1987; Repsol Company, unpublished data) provide a good control for the configuration of the main discontinuities in the shallow structure. A previous interpretation of this profile by Medialdea (1983) and Medialdea et al. (1986) only used wide-angle data.

The ILIHA experiment (ILIHA DSS Group, 1993), with a star-shaped arrangement of six longrange $800 \mathrm{~km}$ profiles crossing the entire Iberian Peninsula, was carried out in 1989. In the southwest of the Iberian Peninsula, the profiles that belong to the ILIHA project (lines 4 and 5 in Fig. 2) extend northeastward from the Mesozoic cover of the Algarve through the Iberian Massif. We have only considered the first $250 \mathrm{~km}$ of the lines that correspond to shots D1 and D2, which are situated very close to one another (Fig. 2). Although these two lines traverse the same tectonic structures, they were recorded at different azimuths.

The Trigueros-Santa Olalla profile (line 3 in Fig. 2) was recorded along a line of $84 \mathrm{~km}$ length, with sensors deployed at a nominal spacing of 4 $\mathrm{km}$, along the South Portuguese zone. The gap in the first $50 \mathrm{~km}$ of profile over the Guadalquivir Basin was due to the presence of a swamp/marsh area. Three shots were recorded, with different frequency contents, over the entire distance range, due to the combination of different charge sizes and water depths in each shot. In this paper, we mainly show the record-section corresponding to the central shotpoint. Arrivals of the other two shotpoints were used only in the definition of the correlations and not in the computation of the model, because these shotpoints were located $13 \mathrm{~km}$ off-line.

In addition to the above profiles and as a continuation of the Ayamonte-Trafalgar profile, in 1970 two seismic lines were recorded across the South Portuguese zone, so close to one another that they can be considered as one reversed profile, extending 180 $\mathrm{km}$ along a SE-NW direction, from the Mesozoic 
cover of the Algarve to the Sines Massif. Demolition charges, depth charges and torpedo heads supplied by the Portuguese Navy were used for the explosions, and were fired at the south coast of Portugal and near the Sines cape. Profile Sines-Azinhal (line 6 in Fig. 2) was the first deep seismic sounding carried out in the Iberian Peninsula and was followed by the profile Fuzeta-Cabo da Roca (line 7 in Fig. 2). These data have been digitized for the present study. Seismic velocity information derived from the Fuzeta-Cabo da Roca and Sines-Azinhal reversed wide-angle reflection/refraction profiles is used to constrain the deep crustal structure of the South Portuguese zone. On these two lines, the average separation of field stations was $5 \mathrm{~km}$.

\section{Methods of interpretation}

To estimate an appropriate velocity-depth structure, trial and error modelling of P-wave traveltime and amplitude information have been used. All the seismic data presented in this work have been interpreted using ray-tracing techniques computing P-wave travel-time and synthetic seismograms (Spence et al., 1984). Amplitudes of arrivals are modelled to provide an additional, and sometimes the only, constraint on particular features of the velocity model, especially for those zones where refracted waves are not visible on the record-sections. A higher priority is placed on fitting the traveltime data. Only large-scale amplitude variations are modelled due to the sensitivity of amplitudes to small-scale phenomena.

Only one profile is reversed. However, the layout of different experiments provides partially reversed, crossing and common shotpoint profiles, which have allowed us to check models first with 1-D and then with 2-D ray-tracing.

On almost all profiles similar seismic phases can be correlated, but the appearance of the individual phases varies from profile to profile. The segments drawn in the record-sections indicate the modelled travel-time curves of the different seismic phases. First arrivals can be separated into various branches, which constrain the depth and velocity in the sedimentary layers (Ps), at the basement (Pg) and upper mantle (Pn) levels. The sedimentary layers were also constrained with complementary information (surface geology, seismic reflection profiles and boreholes). In some record-sections other first-arrival segments have been identified (PB). In later arrivals the most prominent phase on all profiles is the one reflected from the crust-mantle boundary (PMP). Two more horizons separating the middle and the lower crust are inferred from reflected secondary seismic phases (P1P and P2P)

The structure of the middle to lower crust was determined by joint analysis of wide-angle reflections, less readily resolved on some record-sections, due to local complexities in the crustal structure or lower frequency content in the seismic traces. Reflections in the middle and lower crust boundaries are not clearly observable in all record-sections. Thus, greater uncertainty exists for the velocity structure of this layers than for the other parts of the models.

\section{Data interpretation}

\subsection{Gulf of Cadiz area}

\subsubsection{Sedimentary layers}

Seismic reflection data (seismic reflection lines, isopach maps) and bore-hole information has allowed us to trace a detailed structural model of the uppermost crust in the Gulf of Cadiz, in the area sampled by the Ayamonte-Trafalgar profile. This model is shown in Fig. 3. The sedimentary layers gently thicken towards the southeast in the first half of the profile. In the seismic reflection lines (Bonnin et al., 1975; Lajat et al., 1975; Repsol company, unpublished data) a distinct formation is recognized by a number of diffractions where reflections are absent or discontinuous, masking reflectors beneath it. This is an allochthonous structure. Bore-holes located along the border of the Subbetics show Triassic materials, which are incompatible with an insitu slowly deposite formation, implying a chaotic mass overimposed to pre-existing tectonic structures and resembling a widespread nappe or olistostrome (Perconig, 1960-62). Its emplacement took place by sliding since Tortonian until present times (in the lowest areas), in front of the Rif and Subbetic nappes in a Miocene marine basin. This olistostrome structure spreads over a large area, from the Guadalquivir 


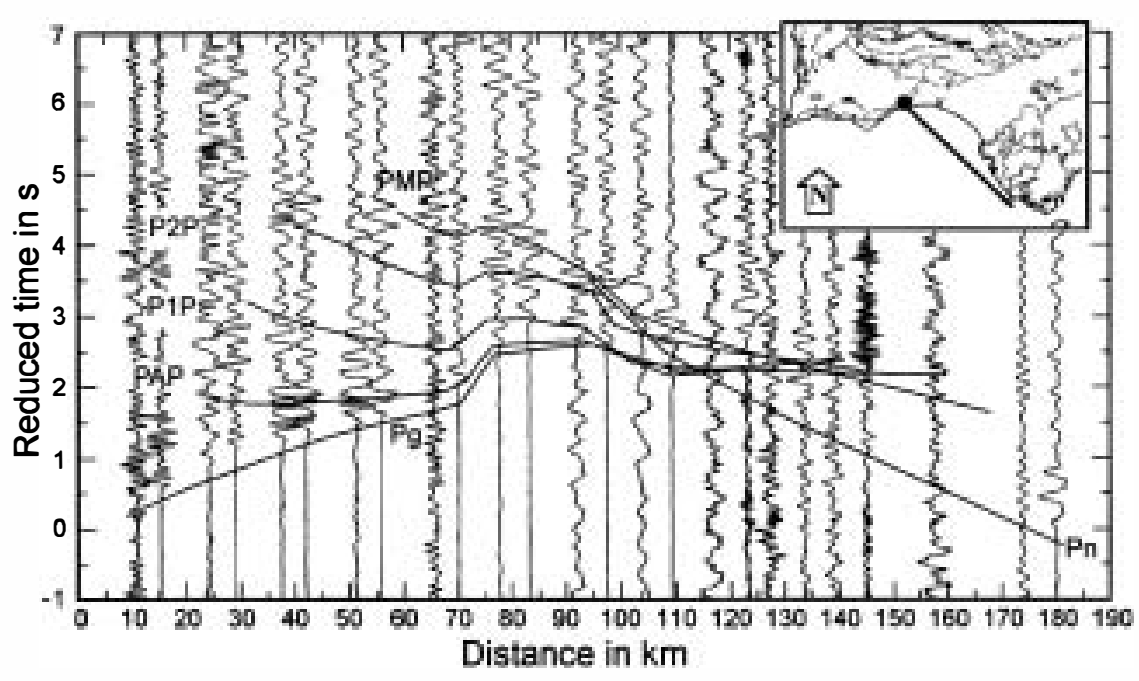

a
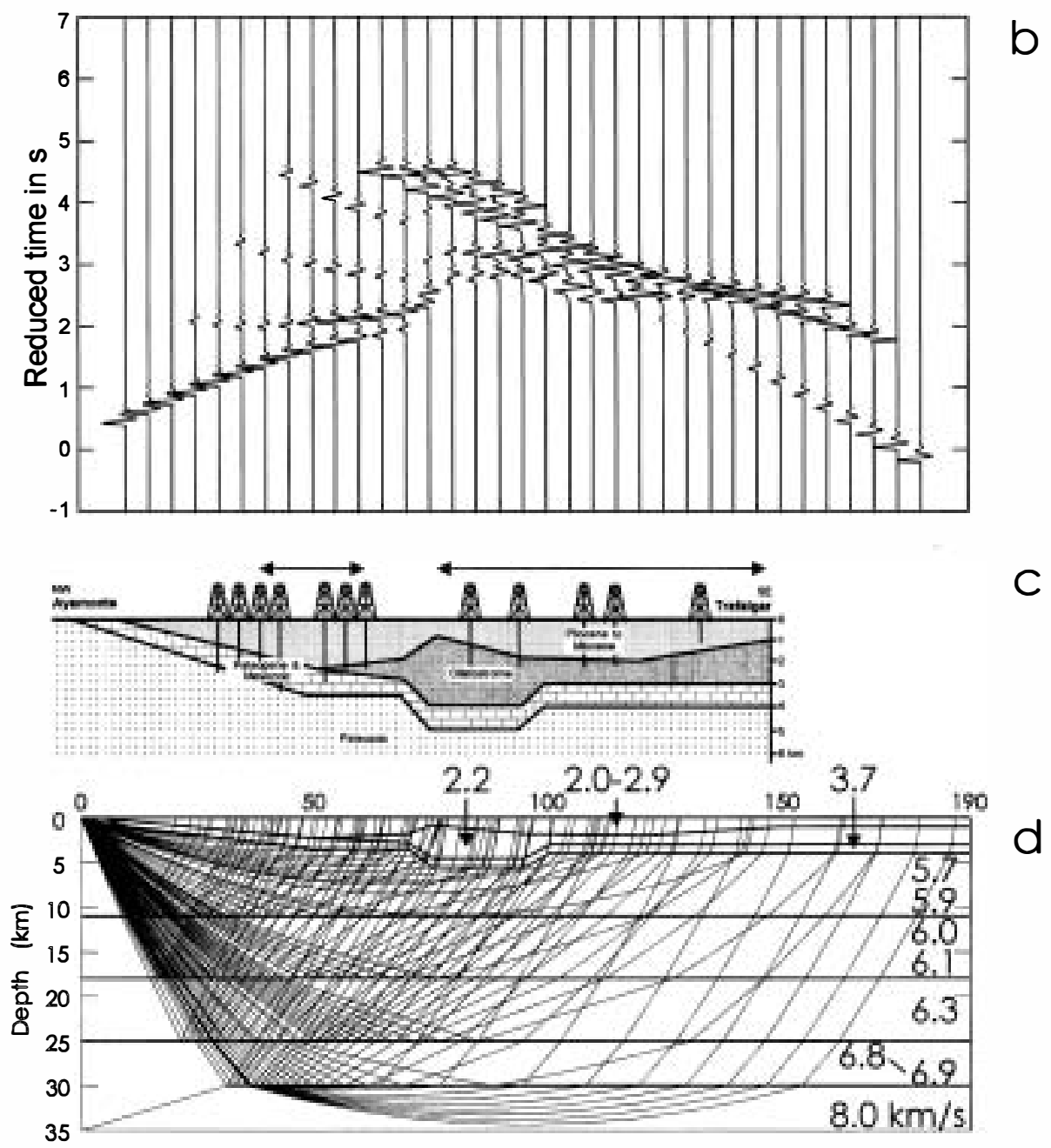
Basin to the Horseshoe abyssal plain and Gorringe and Ampere banks, $450 \mathrm{~km}$ west of the Strait of Gibraltar (Bonnin et al., 1975; Lajat et al., 1975).

First arrivals $(\mathrm{Pg})$ of the Ayamonte-Trafalgar profile (Fig. 3) show apparent velocities increasing with distance from $4.9 \mathrm{~km} / \mathrm{s}$ to a value of $5.4 \mathrm{~km} / \mathrm{s}$ at $70 \mathrm{~km}$ distance. A remarkable feature of the seismic phases of this profile is the $0.7 \mathrm{~s}$ delay time observed for the arrivals beyond $70 \mathrm{~km}$. This delay could be produced by the olistostrome structure, characterized by low P-wave velocities $(2.2 \mathrm{~km} / \mathrm{s})$. Analysis of refraction data, adjusting carefully first arrivals, together with additional detailed information from the Repsol Company, allowed to model the olistostrome structure and the shallow crust (Fig. 3c). This model of the shallow crust for the eastern Gulf of Cadiz is very similar to the model proposed by other authors (Perconig, 1960-62; Martínez del Olmo et al., 1984) for the Guadalquivir Basin.

The record-section for the Chipiona-Arcos de la Frontera profile (see Fig. 4) shows a large delay time of all the phases (almost $5 \mathrm{~s}$ ). This feature could be due to a thick sedimentary cover with low velocities in the Gulf of Cadiz. The shotpoint is located over a local maximum thickness $(3 \mathrm{~km})$ of the olistostromic structure (see Fig. 3c). The sedimentary thickness strongly increases towards the Gulf of Cadiz. This fact explains the high apparent velocity of the Pg phase as was pointed out by Medialdea et al. (1986). These upper crustal first arrivals are characterized by a pronounced amplitude decay at offsets larger than $50 \mathrm{~km}$

\subsubsection{Sub-sedimentary layers}

In the Ayamonte-Trafalgar profile (Fig. 3), beneath the sedimentary layers, seismic velocity jumps from 3.7 to $5.7 \mathrm{~km} / \mathrm{s}$. An arrival, marked as PAP in Fig. 3, is observed $1.5 \mathrm{~s}$ later than the $\mathrm{Pg}$ at a distance of $25 \mathrm{~km}$. This arrival is interpreted as reflected waves from the base of the upper crust discontinuity at a depth of $11 \mathrm{~km}$, where the velocity jumps to $6.0 \mathrm{~km} / \mathrm{s}$. Phases marked as P1P and P2P, that can be observed between 50 and $90 \mathrm{~km}$ from the shotpoint, correspond to wide-angle reflections in middle to lower crust boundaries. The middle crust is characterized by two layers with velocities of 6.0 and $6.3 \mathrm{~km} / \mathrm{s}$. The lower crust is modelled with an increasing velocity from 6.8 to $6.9 \mathrm{~km} / \mathrm{s}$. The PMP is observable at offsets greater than $50 \mathrm{~km}$. Due to a low signal/noise ratio, the Pn cannot be correlated, but synthetic amplitude modelling of the PMP phase (Fig. 3), its critical distance $(70 \mathrm{~km})$ and calculation of travel-times suggest that a velocity step from $6.9 \mathrm{~km} / \mathrm{s}$ to $8.0 \mathrm{~km} / \mathrm{s}$ across the Moho interface, lying at $30 \mathrm{~km}$ depth, produces a satisfactory correspondence with the seismic refraction/wide-angle reflection data. This value of $30 \mathrm{~km}$ for the crustal thickness in the eastern Gulf of Cadiz is higher than the values proposed by previous interpretations (Grupo de Trabajo de perfiles sísmicos profundos, 1983; Medialdea, 1983; Medialdea et al., 1986). Although upper crustal reflectors dip gently towards the southeast in the first half of the profile, deeper layers have been modelled as subhorizontal planar reflecting horizons, situated at 11,18 and $24 \mathrm{~km}$ depth. In Fig. 3 the synthetic seismograms computed for Ayamonte-Trafalgar are shown.

For the Chipiona-Arcos de la Frontera profile (Fig. 4), a phase with high amplitudes, marked as $\mathrm{PAP}$, appears just after the $\mathrm{Pg}$ arrivals. This PAP phase has been interpreted as reflected waves from a discontinuity at a depth of $11 \mathrm{~km}$, with a velocity jump of 5.8 to $6.0 \mathrm{~km} / \mathrm{s}$. A series of coherent wide-angle reflections, marked as $\mathrm{P} 1 \mathrm{P}$ and $\mathrm{P} 2 \mathrm{P}$, are observed at offsets between 35-60 km and 35-75 $\mathrm{km}$, respectively. These two phases have been interpreted by means of two velocity steps in the middle to lower crust from 6.0 to $6.3 \mathrm{~km} / \mathrm{s}$ and from 6.3 to $6.8 \mathrm{~km} / \mathrm{s}$. The PMP has been correlated beyond $45 \mathrm{~km}$. In this profile, this phase is not very prominent. Because of the short range of observation, no Pn phase could be identified in this record-sec-

Fig. 3. (a) Record-section of the Ayamonte-Trafalgar profile including modelled traveltimes. Traces are scaled to a conmnon mavimum amplitude. A band-pass filter of 1 to $20 \mathrm{~Hz}$ and $6 \mathrm{~km} / \mathrm{s}$ reduction velocity were applied. (b) Calculated synthetic record-section for profile Ayamonte-Trafalgar. (c) Uppermost crustal model and geological interpretation, based on reflection and refraction seismic profiles and bore-hole information. Arrow-lines indicate the zone covered by connnercial seismic reflection data. The left zone provides information to the Palaeozoic basement. The right zone offers information until the top of the olistostrome. (d) Ray-tracing. The numbers inside the model show the velocities in $\mathrm{km} / \mathrm{s}$. Vertical exaggeration $\sim 2: 1$. 

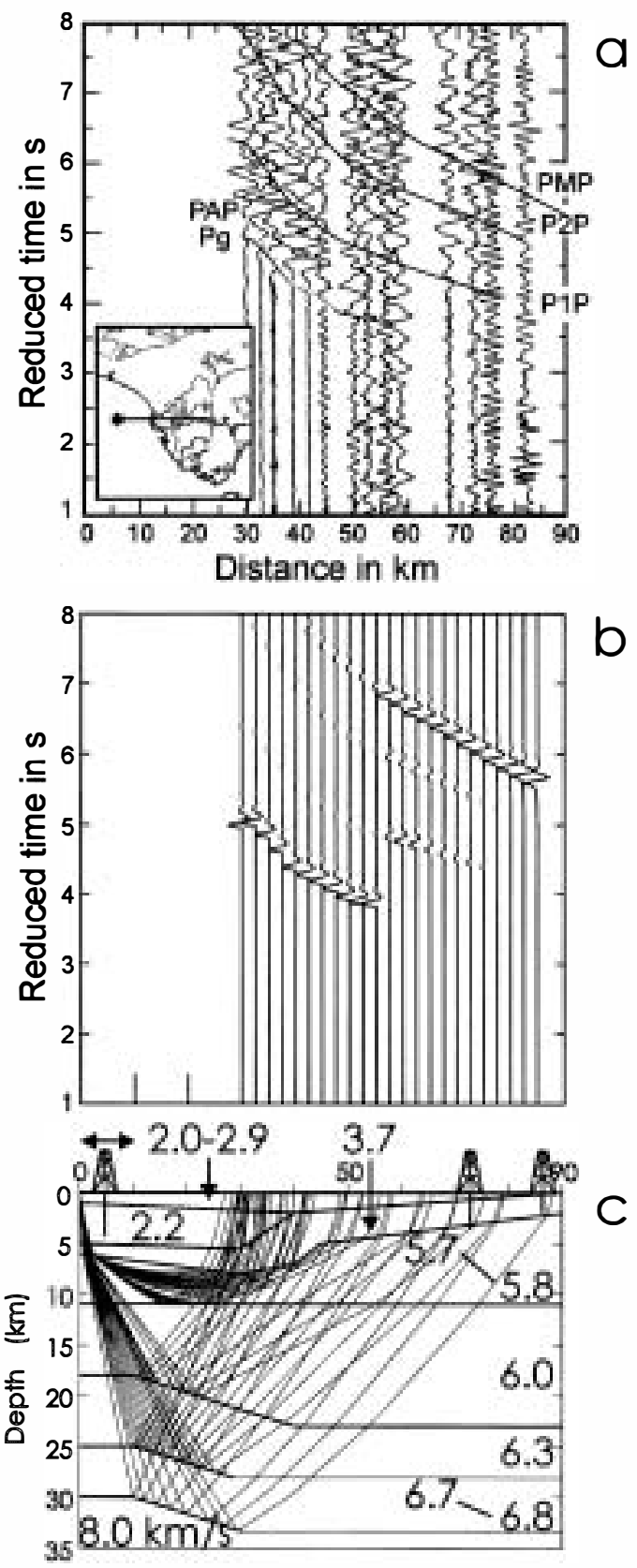

Fig. 4. (a) Record-section of the Chipiona-Arcos de la Frontera profile with trace-normalized amplitudes. A band-pass filter of 1 to $20 \mathrm{~Hz}$ and $6 \mathrm{~km} / \mathrm{s}$ reduction velocity were applied. (b) Calculated synthetic record-section for profile Chipiona-Arcos de la Frontera. (c) Ray-tracing. The numbers inside the model show the velocities in $\mathrm{km} / \mathrm{s}$. Vertical exaggeration $\sim 2: 1$. tion. Travel-time computations of P1P, P2P and PMP phases implied that the thickness of the crust increases towards the Betic Chain in this area, from $30 \mathrm{~km}$ to $34 \mathrm{~km}$. This crustal thickening could be related to the overthrust of the Alboran block into the Gibraltar Thrust.

\subsection{Guadalquivir Basin/Iberian Massif contact}

\subsubsection{Sedimentary layers}

For the ILIHA project profiles (Fig. 5; ILIHA DSS Group, 1993; González et al., 1994), the sedimentary layer is poorly constrained, because the first seismograms are about $20 \mathrm{~km}$ away from the shotpoint.

Through the absence of receivers along the first $50 \mathrm{~km}$ of the Trigueros-Santa Olalla profile (Fig. 5) the velocity structure of the sedimentary layers cannot be resolved. Some of the shots in the Gulf of Cadiz for the Ayamonte-Trafalgar profile were also recorded along the Trigueros-Santa Olalla profile. The results obtained suggest that it is reasonable to assume a lateral homogeneous velocity structure, with respect to the Ayamonte-Trafalgar profile, in the Ayamonte area in the shallow crust around the shotpoints. The velocity-depth distribution obtained in the Ayamonte-Trafalgar profile is introduced in the model to calculate the deeper layers.

\subsubsection{Sub-sedimentary layers}

First arrivals refracted through the upper crust (Pg) for the ILIHA D profiles have an apparent velocity of $6.0 \mathrm{~km} / \mathrm{s}$ at up to $90 \mathrm{~km}$ distance (Fig. 5). The more prominent arrivals, Moho reflections (PMP), are observed beyond $50 \mathrm{~km}$ distance (Fig. 5) and can be identified at offsets of up to 150 $\mathrm{km}$. At greater offsets, clear arrivals correspond to reflections in the middle and lower crust, as continuation of $\mathrm{P} 1 \mathrm{P}$ and $\mathrm{P} 2 \mathrm{P}$ branches. The vertical velocity gradient of the lower crust was adjusted to $0.04 \mathrm{~km}$ $\mathrm{s}^{-1} \mathrm{~km}^{-1}$ to ensure that PMP rays could not propagate to offsets larger than $150 \mathrm{~km}$. Weak refracted waves Pn can be correlated beyond $100 \mathrm{~km}$ distance, with an apparent velocity of $8.0 \mathrm{~km} / \mathrm{s}$. This weak phase can be explained by a low vertical velocity gradient of $0.007 \mathrm{~km} \mathrm{~s}^{-1} \mathrm{~km}^{-1}$ in the uppermost mantle. Both ILIHA D record-sections (Fig. 5; ILIHA DSS Group, 1993; González et al., 1994) show 
similar features, with respect to the range of observation, arrival times and the amplitude behaviour of seismic phases. Another feature of these record-sections is the low frequency of the seismograms (near $3 \mathrm{~Hz}$ ). This can be explained by the large charges used to carry out the shots (about $1000 \mathrm{~kg}$ ) and the dispersed charge method (Jacob, 1975; ILIHA DSS Group, 1993). The low frequency of the seismograms masks the energy reflected in the middle and lower crust.

The Trigueros-Santa Olalla profile intersects the ILIHA D2 profile (see Fig. 5) and allows us to define more clearly some of the phases from the middle and lower crust. In the Trigueros-Santa Olalla profile smaller explosion charges (100 to $400 \mathrm{~kg}$ ) were used, resulting in higher frequency $(6 \mathrm{~Hz})$ than that obtained in the ILIHA shots $(3 \mathrm{~Hz})$. This fact implies that the Trigueros-Santa Olalla provides more information on the discontinuities of the middle and lower crust in the crossing area with ILIHA lines. That is, the Trigueros-Santa Olalla profile allows to apply to the ILIHA data analogous phase correlations, which would have seemed problematic otherwise. First arrivals $(\mathrm{PB}$ in Fig. 5) display an apparent velocity of $6.2 \mathrm{~km} / \mathrm{s}$. This apparent velocity can be explained by means of rays propagating into a layer deepening beneath the crystalline basement with a velocity of $6.0-6.1 \mathrm{~km} / \mathrm{s}$. Ulterior energy arrivals, phases labelled as P1P and P2P, correspond to velocity steps into the middle to lower crust boundaries from 6.1 to 6.4 and from 6.5 to $6.7 \mathrm{~km} / \mathrm{s}$, respectively. The PMP phase is the most prominent one and is identified beyond a distance of $60 \mathrm{~km}$ as an over-critical phase. Refracted waves Pn in the upper mantle emerge as a first arrival at source-receiver ranges of $12 \mathrm{~km}$ with an apparent velocity of $8.0 \mathrm{~km} / \mathrm{s}$. The computed seismic velocity model shows a slightly thinned crust $(29 \mathrm{~km})$ in the area corresponding to the boundary between the Iberian Meseta and the Guadalquivir Basin. This thinning appears to correlate with the topographic elevations of the Sierra Morena.

\subsection{South Portuguese zone}

\subsubsection{Sedimentary layers}

The Fuzeta-Cabo da Roca and Sines-Azinhal profiles show only two seismograms where near-surface arrivals Ps are observed (Fig. 6), at a distance range between 0 and $20 \mathrm{~km}$, so no detailed specification of the velocity structure of sedimentary layers is possible. A linear velocity-depth function was used to represent the uppermost layer in the model, which yielded an increasing velocity with depth from 4.5 to $4.8 \mathrm{~km} / \mathrm{s}$ near Sines (to a depth of $2 \mathrm{~km}$ ) and from 4.3 to $4.7 \mathrm{~km} / \mathrm{s}$ (to a depth of $3 \mathrm{~km}$ ) in the Algarve.

\subsubsection{Sub-sedimentary layers}

In these profiles (Fig. 6), we have correlated a $\mathrm{Pg}$ phase with an apparent velocity of $6 \mathrm{~km} / \mathrm{s}$, appearing as first arrival in a distance range of $20-50 \mathrm{~km}$. One of the most prominent features of this record-section is a high apparent velocity $(6.4 \mathrm{~km} / \mathrm{s})$ first arrival segment, following phase $\mathrm{Pg}$, observed on profiles Sines-Azinhal and Fuzeta-Cabo da Roca ( $\mathrm{PB}$ in Fig. 6). These first arrivals coming from a deeper level of the upper crust are possibly related to the ultramafic rocks outcropping in the Beja-Acebuches zone. This high velocity of $6.4 \mathrm{~km} / \mathrm{s}$ is observed at relatively shallow depths. The top of this layer dips southeast from a depth of about $7 \mathrm{~km}$ at the northwestern end, near cape Sines, to nearly $10 \mathrm{~km}$ depth beneath Serra do Caldeirao, on the southeast limit of the model (Fig. 6). There is no evidence of a low-velocity layer extending beneath the South Portuguese zone. In previous interpretations of Portuguese profiles (Mueller et al., 1973; Prodehl et al., 1974; Sousa Moreira et al., 1977) using analog data, correlation of the first arrivals was interrupted at $90 \mathrm{~km}$. This phase ending abruptly implied a low-velocity layer in the crust. A blow-up of the first arrivals (see Fig. 6), using digital data, shows that the first-arrival correlation can be seen as far as $140-150 \mathrm{~km}$. The apparent velocity of these first arrivals does not increase with distance, which indicates that there is not an important velocity gradient in this layer, as previously modelled. Those features motivated us to propose a new crustal model for the area. Fig. 6 shows a synthetic seismogram calculation for the Sines-Azinhal profile. The twodimensional seismic velocity model derived from these refraction/wide-angle reflection data shows a layer with a velocity of $6.4-6.5 \mathrm{~km} / \mathrm{s}$. In order to reduce the theoretical amplitudes of the PMP phase and to increase its critical distance (to $65-70 \mathrm{~km}$ ), a positive gradient for the P-wave velocity was introduced in the lower crust, which is modelled with 

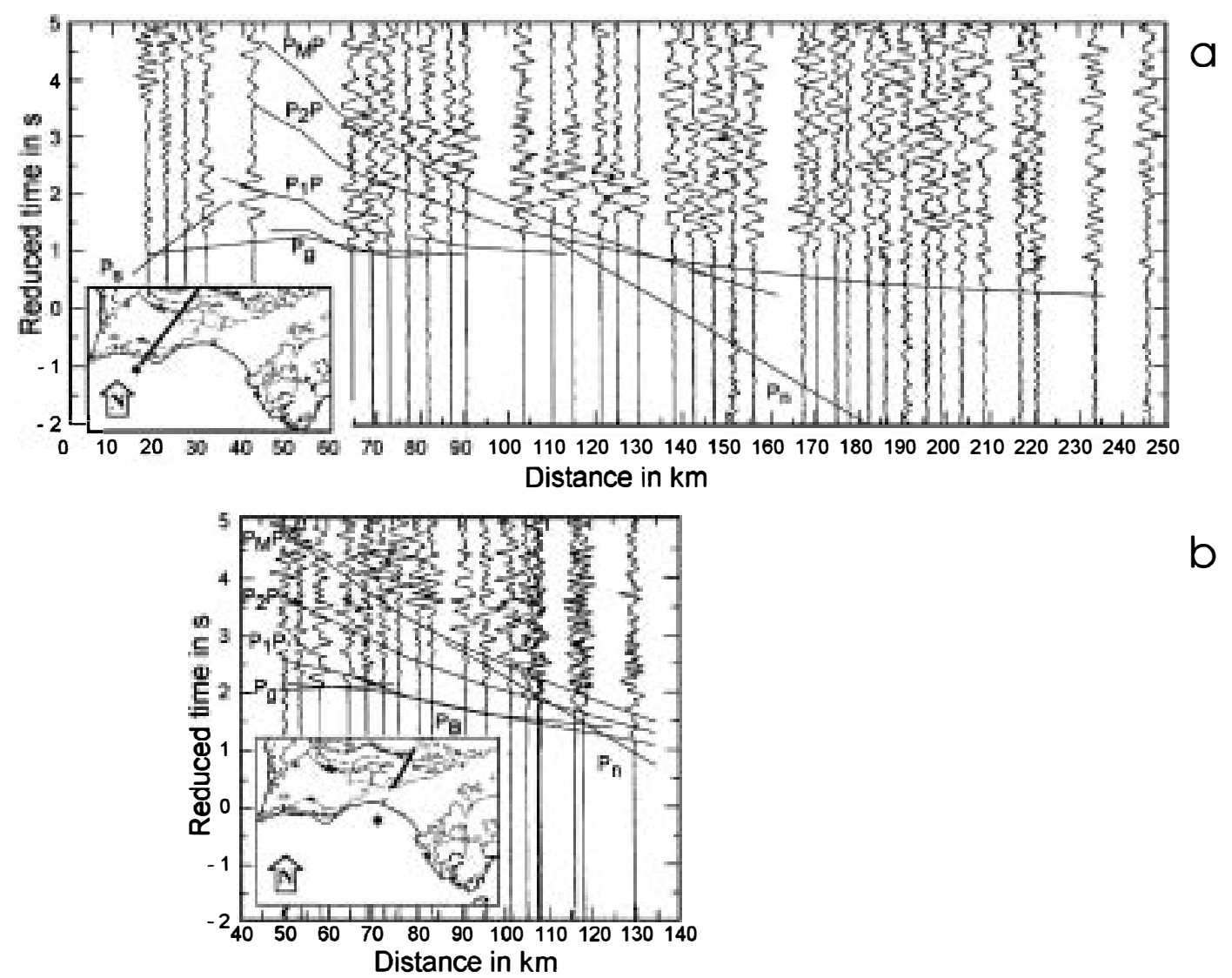

b
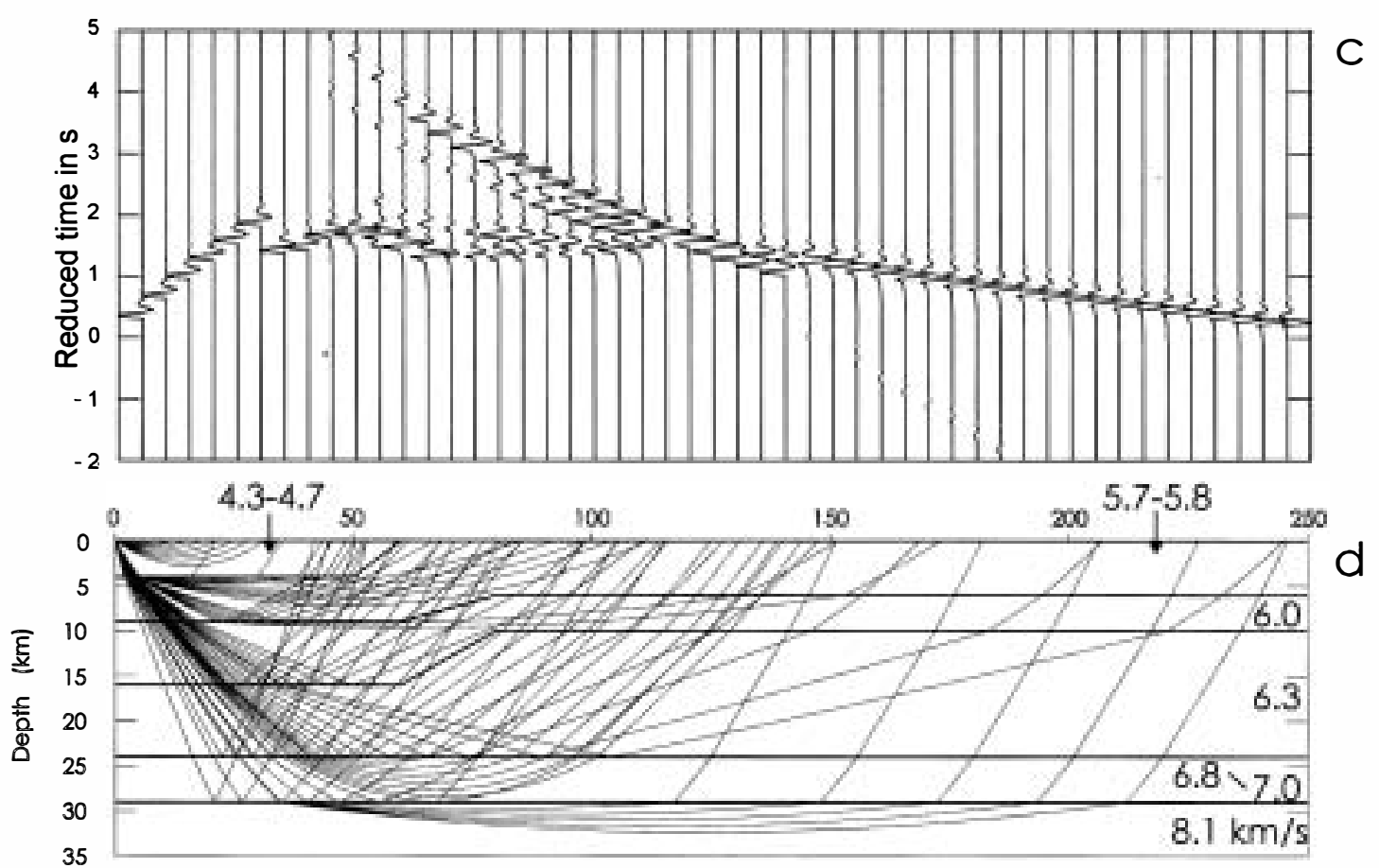
a velocity increase from 6.7 to $6.9 \mathrm{~km} / \mathrm{s}$ dipping gently southeastward. The depth of the Moho varies from near $35 \mathrm{~km}$ in the southeast to $31 \mathrm{~km}$ in the area of Sines. The upper mantle velocity of $8.0 \mathrm{~km} / \mathrm{s}$ is derived from PMP amplitudes, its critical distance and some Pn arrivals.

\section{Discussion}

Data from over $1200 \mathrm{~km}$ of wide-angle seismic reflection/refraction profiles along seven transects in the southwestern Iberian Peninsula and the Gulf of Cadiz, together with commercial reflection seismics, bore-holes and surface geology information, have been used to develop a structural and tectonic model, which constitutes an important contribution to the understanding of the crustal structure and its evolution in the area. The seismic model obtained shows interesting features with regard to the detailed topography of the discontinuities, the thickness of the crust and differences in the distribution of the propagation velocities of P-waves.

The velocity distribution within the crust is different beneath each profile. The velocities of the uppermost crust in the Gulf of Cadiz are lower than on land, due to the Tertiary and Quatemary sedimentary infill, underlain by a Mesozoic calcareous bottom layer. In the Gulf of Cadiz the upper crust structure is well defined from seismic reflection and bore-hole data.

Below the sedimentary layers, the upper crust is characterized by a velocity range of $5.7-6.1 \mathrm{~km} / \mathrm{s}$. The velocity of $5.7 \mathrm{~km} / \mathrm{s}$ for the uppermost basement is due to the existence of rocks of mainly Carboniferous age that outcrops in the South Portuguese zone. The almost constant velocity of $5.7 \mathrm{~km} / \mathrm{s}$ for the uppermost basement implies that the same type of basement can be found below the sedimentary cover in other parts of the area. This layer deepens to the southeast and underlines post-Tertiary sediments in the Gulf of Cadiz/Guadalquivir Basin and the nappes of the External Betic Cordilleras. The bottom of the upper crust is located at a depth ranging from $11 \mathrm{~km}$ in the Gulf of Cadiz, as indicated by Medialdea et al. (1986), to $7 \mathrm{~km}$ beneath the northwestern part of the South Portuguese zone.

One of the most striking results obtained from the interpretation of seismic data in the area is the high apparent velocity $(6.4 \mathrm{~km} / \mathrm{s})$ observed at relatively shallow depth in the South Portuguese zone, suggesting the existence of mafic and ultramafic rocks in the upper levels of the crust $(7 \mathrm{~km}$ in the Sines area and $10 \mathrm{~km}$ in the south). A velocity of $6.4 \mathrm{~km} / \mathrm{s}$ corresponding to the first arrivals at a distance between 30 and $160 \mathrm{~km}$, visible in the record-sections Fuzeta-Cabo da Roca and Sines-Azinhal, is higher than usually recorded for such a distance range in other zones of the Iberian Massif. ILIHA DSS Group (1993) reports $6.3 \mathrm{~km} / \mathrm{s}$ at a depth of $12 \mathrm{~km}$ for the profile $\mathrm{C}-\mathrm{F}$, in an area to the north of Sines. The South Portuguese terrane was accreted by the Hercynian orogeny to the Iberian autochthon. The Ossa-Morena and South Portuguese terranes come from different and previously differentiated crusts, explaining the exotic nature of the South Portuguese crust with respect to the rest of the Iberian Massif, with a thickened middle crust. Beja-Acebuches ophiolites and oceanic sedimentary sequences of the Pulo do Lobo terranes were obducted during the Hercynian orogeny (Munha et al., 1989) and accretion of the South Portuguese terrain. The existence of this oceanic lithosphere-related rocks can explain the high velocities in upper levels of the crust in the South Portuguese zone. In the rest of the area, the middle crust has a thickness of $7 \mathrm{~km}$.

Below this layer of $6.4 \mathrm{~km} / \mathrm{s}$, the top of the lower crust lies at a depth of $24-25 \mathrm{~km}$ in the entire area and is characterized by an increase in velocity from 6.7 to $6.9 \mathrm{~km} / \mathrm{s}$. The velocity-depth function is modelled by a gradually increasing velocity in the lower crust, with a gradient of $0.03 \mathrm{~km} / \mathrm{s} / \mathrm{km}$. The low frequency of the seismograms does not allow to investigate in detail the reflectivity of the lower crust. However, the relative amplitudes of PlP and $\mathrm{P} 2 \mathrm{P}$ phases suggest that the impedance contrast in

Fig. 5. Record-sections for: (a) ILIHA shot D1 profile; (b) Trigueros-Santa Olalla profile. Trace amplitudes are normalized. A band-pass filter of 1 to $20 \mathrm{~Hz}$ and $6 \mathrm{~km} / \mathrm{s}$ reduction velocity were applied. (c) Calculated synthetic record-section for profiles ILIHA D1-D2. (d) Ray-tracing. The numbers inside the model show the velocities in $\mathrm{km} / \mathrm{s}$. Vertical exaggeration $\sim 2: 1$. 


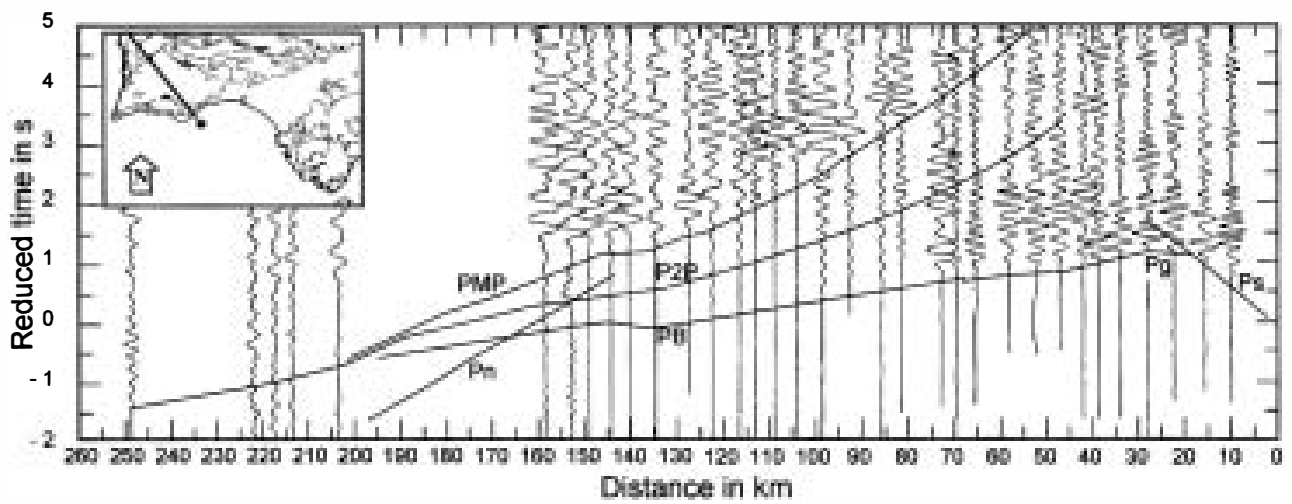

a

b
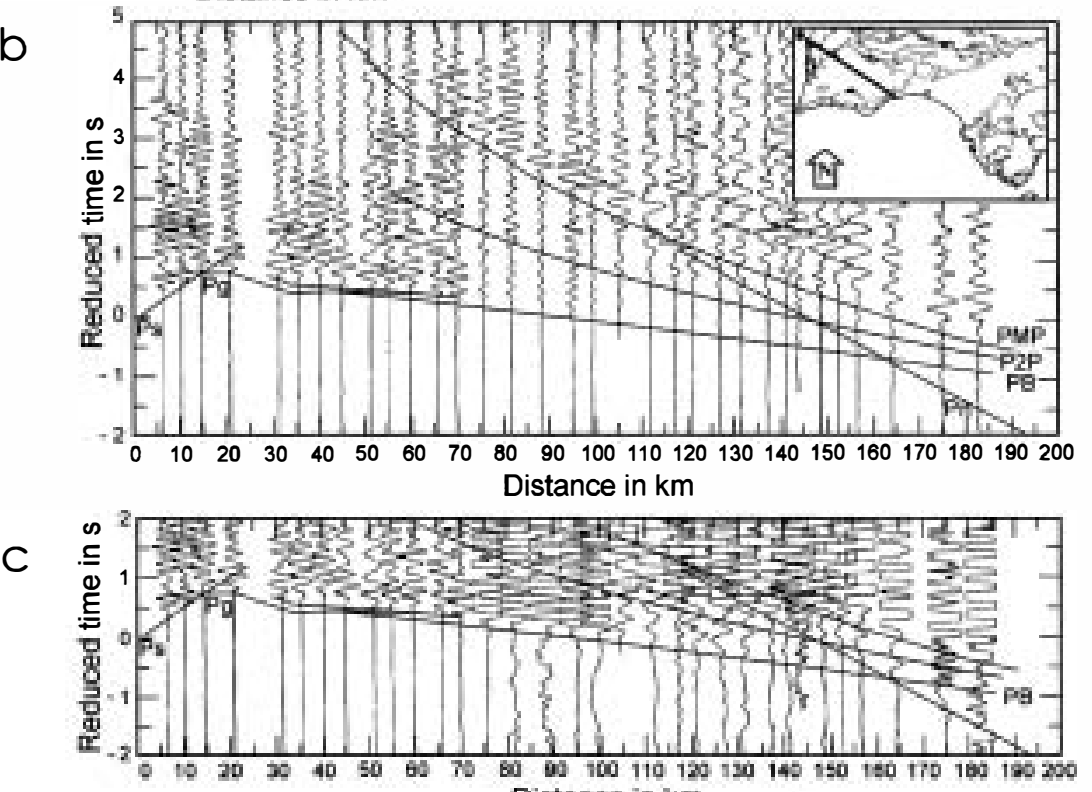
Distance in $\mathrm{km}$

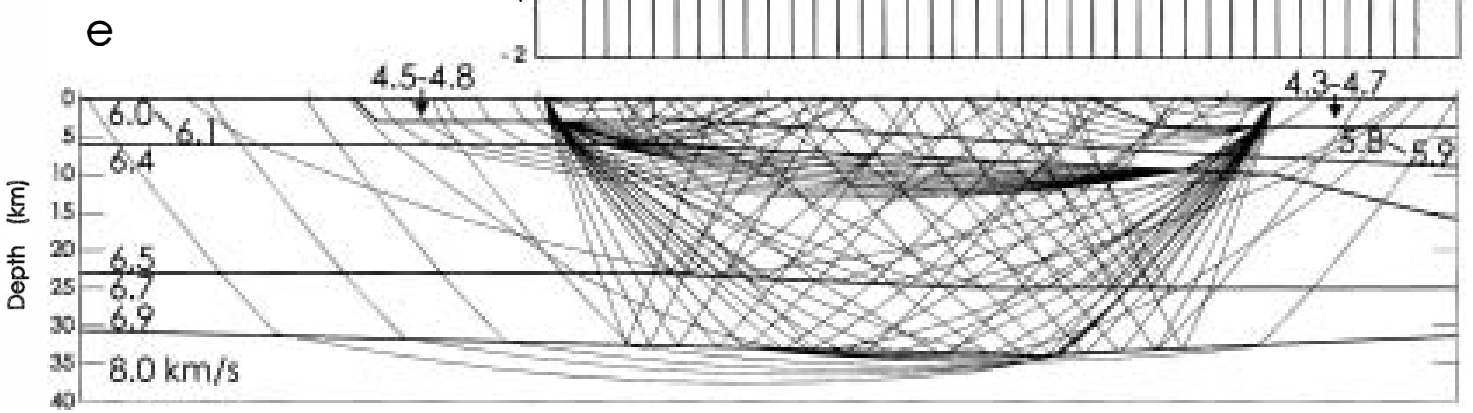




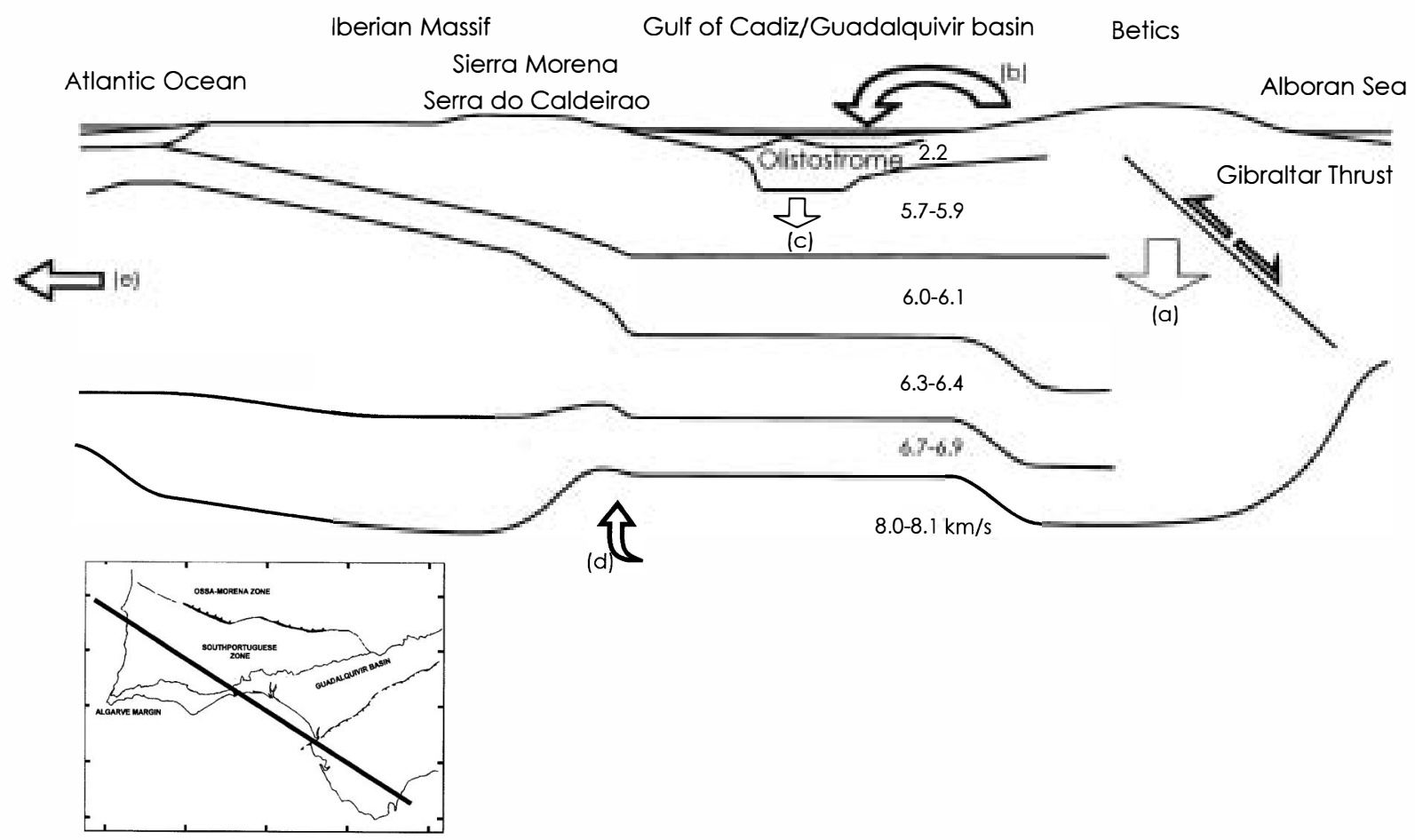

Fig. 7. Geodynamic evolution model obtained from the interpretation of profiles 1-7 (Fig. 2), from the Atlantic Ocean to the Alboran Sea, crossing the Gulf of Cadiz. The numbers inside the model show the velocities in $\mathrm{km} / \mathrm{s}$. (a) Overload due to Gibraltar Thrust. (b) Infilling of the Gulf of Cadiz/Guadalquivir Basin. (c) Overload produced by the sedimentary cover. (d) Elastic rebound of the crust due to the overload of the Alboran Domain. (e) Extensional stress caused by the opening of the Atlantic Ocean. Vertical exaggeration $4: 1$.

the middle/lower crust discontinuity is higher than in the upper/middle crust discontinuity. This implies that the velocity contrast is higher in the first discontinuity mentioned $(6.0-6.1 / 6.3-6.4 \mathrm{~km} / \mathrm{s})$ than in the second one $(6.3-6.4 / 6.7-6.8 \mathrm{~km} / \mathrm{s})$. The PMP phase and the interpreted velocity gradient in the lower crust suggest the presence of a lamellar structure of the deeper crust, as has been postulated by several authors (Meissner, 1967; Fuchs, 1969; Davydova et al., 1972; Deichmann and Ansorge, 1983).

Some profiles were observed up to distance ranges where Pn arrivals should be recorded. The weak (or even lack of) Pn phase is due to a low vertical velocity gradient of $0.010-0.007 \mathrm{~km} \mathrm{~s}^{-1} \mathrm{~km}^{-1}$ in the uppermost mantle. In places where the Pn phase cannot be identified, due to a low signal/noise ratio, synthetic amplitude modelling of the PMP reflected phase, its critical distance and computation of traveltimes allowed to model the Moho boundary. The crust-mantle boundary is interpreted as a first-order discontinuity, due to the use of low-frequency seismograms, being similar to the results obtained for all the profiles, as indicated by the velocity jump from $6.8-6.9 \mathrm{~km} / \mathrm{s}$ to $8.0-8.1 \mathrm{~km} / \mathrm{s}$. The thickness of the

Fig. 6. Profiles Fuzeta-Cabo da Roca (a) and Sines-Azinhal (b) including correlated seismic phases. (c) Blow-up views of first arrivals for the Sines-Azinhal profile. Normalized amplitudes. A band-pass filter of 1 to $20 \mathrm{~Hz}$ and $6 \mathrm{~km} / \mathrm{s}$ reduction velocity were applied. (d) Calculated synthetic record-section for the profile Sines-Azinhal. (e) Ray-tracing for the Fuzeta-Cabo da Roca and Sines-Azinhal profiles. The numbers inside the model show the velocities in $\mathrm{km} / \mathrm{s}$. Vertical exaggeration $\sim 2: 1$. 
crust is variable for the studied area, from $29 \mathrm{~km}$ (Guadalquivir Basin/Iberian Massif contact), to a maximum of $35 \mathrm{~km}$ in the southern part of the South Portuguese zone. In the Sines area (Fig. 2) the Moho is near $31 \mathrm{~km}$ deep, which is in good agreement with previous results (Caetano, 1983). The Moho depth under an area to the north of Sines is $28 \mathrm{~km}$ (ILIHA DSS Group, 1993). Beneath the Gulf of Cadiz, there is a previously thinned crust, which actually maintains an important thickness of $30 \mathrm{~km}$ due to the great amount of sediments. Beneath the central part of the Chipiona-Arcos de la Frontera profile, the Moho depth varies from 30 to $33 \mathrm{~km}$, deepening to the east along a distance of $20 \mathrm{~km}$

\section{Tectonic models}

The crustal models imaged in this paper can be used to constrain tectonic models proposed for this area. In this sense, several points can be emphasized.

West of the Gibraltar Arc, the variations in Moho depth can be related either to the Mesozoic thinning of the Hercynian crust of the Iberian Massif (Lusitanian margin) or to flexures of the crust due to the Tertiary stress transmission and nappe loading in the Guadalquivir Basin (Fig. 7, thinning in the Alboran Sea and overload due to Gibraltar Thrust). This flexure corroborates the nature of the Guadalquivir Basin as a foreland basin and explains the relief of Sierra Morena (and its continuation in Portugal, Serra do Caldeirao) as a consequence of an elastic rebound of the crust (Fig. 7d). This flexural mechanism also supports the continuous infilling of the Guadalquivir Basin and adjacent oceanic areas during the Neogene dismantling of the Betic Cordillera (Fig. 7b,c). The sedimentary overload contributes to the subsidence, but it is not its original cause. To this can be added the clear continuation of the Guadalquivir Basin in the continental margin off the Gulf of Cadiz. Moreover, it can be concluded that Betic deformation (thickening and thinning of the crust) does not continues west of the Strait of Gibraltar. The thinning of the South Portuguese crust to the west (Fig. 7e) may be associated with the opening of the Atlantic Ocean as has previously been suggested (Mueller et al., 1973; Mendes-Victor et al., 1980; ILIHA DSS Group, 1993).
The other important observation described in this paper corresponds to the identification of a relatively high-velocity layer at shallow depth in the South Portuguese zone. This can be correlated with the hypothesis of the oceanic origin of the Pulo do Lobo Antiform (a sort of subduction complex?), and the existence of a layer formed by mafics and ultramafics under the northern part of the South Portuguese zone that resulted from this oceanic realm and that could be linked too with the Beja-Acebuches ophiolite. The convergence of the South Portuguese and OssaMorena terranes during the Variscan orogeny can explain the thickening of the crust in this area.

\section{Acknowledgements}

This research was funded by the Spanish CICYT project ESIGAL and EC projects ENV4-CT97-0547 (BIGSETS). We are grateful to Repsol Exploración that kindly provided us useful data. We also thank Dr. J.J. Dañobeitia for comments and improvement of the manuscript.

\section{References}

Balanyá, J.C., García-Dueñas, V., 1988. El cabalgamiento cortical de Gibraltar y la tectónica de Béticas y Rif. II Congr. Geol. Esp., Granada, pp. 35-44.

Bonnin, J., Olivet, J.L., Auzende, J.M., 1975. Structure en nappe à l' Ouest de Gibraltar. C.R. Acad. Sci. Paris 281, 559-562.

Caetano, H., 1983. Structure crustale de la zone Sud Portugaise et de la zone Ossa-Morena d'aprés les études de sismologie expérimentale. Thèse $3 \mathrm{e}$ cycle, Univ. Paris VI, $144 \mathrm{pp}$.

Dalhnayer, R.D., Martinez García (Eds.), 1992. Pre-Mesozoic Geology of Iberia. Springer-Verlag, Berlin, $416 \mathrm{pp}$.

Davydova, N.I., Kosminskaya, I.P., Kapustian, N.K., Michota, G.G., 1972. Models of the Earth's crust and M-boundary. J. Geophys. 38, 369-393.

Deichmam, N., Ansorge, J., 1983. Evidence for lamination in the lower continental crust beneath the Black Forest (Southwestern Germany). J. Geophys. 52, 109-118.

Fuchs, K., 1969. On the properties of deep crustal reflectors. J. Geophys. 35, 133-149.

García-Dueñas, V., Balanyá, J.C., 1991. Fallas normales de bajo ángulo a gran escala en las Béticas occidentales. Geogaceta 9 , 33-37.

González, A., Córdoba, D., Matias, L.M., Vegas, R., Téllez, J., 1994. A reanalysis of P-wave velocity models in the southwestern Iberian Peninsula-Gulf of Cadiz motivated by the IIHA-DSS experiments. I.G.N. Monogr. 10, 215-227. 
Grupo de Trabajo de perfiles sísmicos profiundos, 1983. Perfiles sísmicos profundos en España 1981. Bol. Geol. Miner. XCIV-IV, 339-347.

IIHA DSS Group, 1993. A deep seismic sounding investigation on lithospheric heterogeneity and anisotropy in Iberia. Tectonophysics 221, 35-51

Instituto Geológico y Minero de España, 1987. Contribución de la exploración petrolífera al conocimiento de la Geología de España, $465 \mathrm{pp}$.

Jacob, A.W.B., 1975. Dispersed shots at optimum depth - an efficient seismic source for lithosphere studies. J. Geophys. 41, 63-70

Lajat, D., Biju-Duval, B., Gonnard, R., Letouzey, J., Winnock, E., 1975. Prolongement dans l'Atlantique de la partie exteme de l'Arc bético-rifain. Bull. Soc. Geol. Fr. 17 4, 481-485.

Martínez del @hno, W., García, J., Leret, G., Serrano, A., Suárez, J., 1984. Modelo tectosedimentario del Bajo Guadalquivir. I Congr. Geol. Esp. I, pp. 199-213.

Medialdea, T., 1983. La estructura de la corteza en el extremo occidental de la Cordillera Bética a partir de perfiles sísmicos de refracción. Su interpretación geodinámica. Tesis de Licenciatura, Univ. of Madrid, $120 \mathrm{pp}$.

Medialdea, T., Suriñach, E., Vegas, R., Banda, E., Ansorge, J., 1986. Crustal structure under the western end of the Betic Cordillera (Spain). Ann. Geophys. B 4, 457-464.

Meissner, R., 1967. Exploring deep interfaces by seismic wide angle measurements. Geophys. Prospect. 15, 598-617.

Mendes-Victor, L.A., Him, A., Veinante, JL., 1980. A seismic section across the Tagus Valley, Portugal: possible evolution of the crust. Ann. Geophys. 36, 469-476.

Mueller, S., Prodehl, C., Mendes, A.S., Sousa Moreira, V., 1973. Crustal structure in the southwestern part of the Iberian Peninsula. Tectonophysics 20, 307-318.

Munha, J., Oliveira, J.T., Ribeiro, A., Quesada, C., Fonseca, P., Castro, P., 1989. Accreted terranes in southern Iberia: the Beja-Acebuches ophiolite and related oceanic sequences. 28th Int. Geol. Congr., Washington, Abstr. 2, 312-314.

Perconig, E., 1960-62. Sur la constitution géologique de 1'Andalousie occidentale, en particulier du bassin du Guadalquivir (Espagne méridionale). Livre à la mémoire du Professeur P. Fallot. Mém. Soc. Géol. Fr. 1, 229-256.

Prodehl, C., Sousa Moreira, V., Mueller, S., Mendes, A.S., 1974. XIVth General Assembly of the European Seismological Commission, Trieste.

Sousa Moreira, V., Mueller, S., Mendes, A.S., Prodehl, C., 1977. Crustal structure of southem Portugal. Publ. Inst. Geophys. Pol. Acad. Sci. A 4 (115), 413-426.

Spence, G.D., Whitehall, K.P., Clowes, R.M., 1984. Practical synthetic seismograms for laterally varying media calculated by asymptotic ray theory. Bull. Seismol. Soc. Am. 74, 12091223. 